\title{
Systematic Types of Fungi of Allocated and Determined Types from Decorative Flowers in Conditions Region Tashkent
}

\author{
S. A. Misirova \\ Tashkent State Agrarian University, Tashkent, Uzbekistan \\ Email:misirova1983surayyo@mail.ru,samisirova@mail.ru
}

Received 16 October 2015; accepted 23 November 2015; published 26 November 2015

Copyright (C) 2015 by author and Scientific Research Publishing Inc.

This work is licensed under the Creative Commons Attribution International License (CC BY). http://creativecommons.org/licenses/by/4.0/

cC) (i) Open Access

\begin{abstract}
For the first time, 658 herbarium specimens planted from the 15 decorative flower plants in the conditions of the Tashkent Region were collected. From them, disease separation including of 65 types of fungi 9 form and 1 variation were determined. They were: 4 classes, 7 sections, 11 families and 30 categories.
\end{abstract}

Keywords

Ornamental Flowers, Fungi Types, Systematic of Disease

\section{Introduction}

The development of floriculture has been deleted of its roots in even the ancient history. According to scientific literature, it involves the history of 3,000 years of floriculture [1]. So, the population all over the world likes the flowers from the ancient times. But at that time, people don't understand members of the generative of flowers.

Selection works are done by amateur during the far years. But after for a long time, well developed floriculture in the most countries becomes one of the most brunch of agriculture which makes a lot of benefits. Because the plants of the world flowers too provoke a graceful feeling of emotionality of the people and it calls people to protect and love our beautiful nature. In addition, flowers are able to make many needs of people. Besides, bat flower used for against various diseases with various tissue products in folk medicine.

Flowers grown at home improves the micro-climate conditions of the rooms, keeps the rooms from the dust, and supply with the oxygen [2].

As we know, flowers cause for disease with different types of fungi as other plants of agriculture. As a result, decorative flowers are brought great harm and decrease the quality of the flowers. Sometimes the flowers will 
have died before opening; the onions will lose for the next year.

In scientific publications, various types of ornamental flowers pathogen spores of diseases identify and develope the methods to reduce the level of the disease of the plants flowers [3]-[6].

At work, the development of [7]-[10] phytopathology science of the Republic of Uzbekistan, identification of plant diseases and produced to fight against them. At this work, they know bioecological features of fungi types which damage agricultural crops and their systematic distribution at laws. Besides that, they professed fighting measures for them and introduced to practice. Nevertheless, flower plants diseases in the city of Tashkent and the regions of Tashkent are not studied by any one.

The main aim of this work is to determinate allocated types of fungi from the ornamental flowers in Tashkent region.

\section{Materials and Methods}

\subsection{Research Sites}

During 3 years our research work is implemented of Tashkent state Agrarian University of seed and plant protection faculty and greenhouse street at Tashkent "Qibray" region of the republic of Uzbekistan. The region which implements the research is situated in the river "Chirchiq" which placed at the middle of the fourth surface of the region in Tashkent. Studied region were detected of the polio climatologic edge of the climatic filature.

Tashkent region was founded on January 5, 1938, is situated in the north eastern part of legated Uzbekistan, it borders on in the north-west with Kazakhstan. It occupies Chatkal, Kurama in the north east and caster part, Pskem and Ugam mountain ranges in the south and in the southern half from the Syr-Darya on the western side of the mountains and plains.

Tashkent is Turan soil and climatic region. One of the most unique features is a variable climate the reason of the changes season is the rapid rise of temperature hot in summer, warm spring and dry summer. The south and southern part of the region is dryer and higher than northern districts. The average air temperature is $14.2^{\circ} \mathrm{C}$ $14.4^{\circ} \mathrm{C}$, at June and July a maximum of $42^{\circ} \mathrm{C}-44^{\circ} \mathrm{C}$, the absolute temperature which is to equal of minus $-29^{\circ} \mathrm{C}$ at the scientific research place.

During the year relative air humidity is $86 \%$ and more than 32 days and it doesn't rain in June and September, the air humidity of the days is 148 never less from it.

The annual amount of the rain is 268 - $359 \mathrm{~mm}$. formed that is 146 - $199 \mathrm{~mm}$. the month of January-April. The most rain is at the middle of March, the annual rain is $300-500 \mathrm{~mm}$. in mountains Ares is $500-1000 \mathrm{~mm}$. Some of the mountains which have moisture climates the rain are $1500-1600 \mathrm{~mm}$.

\subsection{Planting Material}

Knowing scientific literature, I identify the 58 diseases of the flower which belonging diverse to systematic group. We chose15 different crops researching place, the names of these flowers are listed in Table 1. As you see in this table, they are composed of annual and perennial plants. snapdragon, chrysanthemum, carnation, aster-in a an annual, dahlia, gladiolus, hyacinth, iris, Lily, narcisisus, peony, phlox, tulip, roses, an annual plants in the group.

The purpose of choosing 15 types of flowers more than these flowers are planted more than these flowers are planted. Because selected plants are effective are adornment and quality at a high level in economy.

\subsection{Observation and Data Analysis}

Learning of the fungi is mainly using a microscope, anatomic cutting from the methods, moisture cameras, separation of pure cultures of fungi, from cooking artificial environments.

At the same time, we presented the sprouting of plants to the end of the growing season in hothouse and open ground conditions. We pre aperture each members of the diseases of plants: leaves, leaves stems items and twigs, if the plants were scorched, it's from root system flowers and sunflower flowers we herbarium samples at methods of used mycology and phytopathology [11].

We determined types of fungi using a microscope preparation from herbaria in Laboratory conditions. We used from the method of "Moisture" to determine the types of fungi. At the same time fungi plant tissue from through to out wraps, point spore and sporadic be sure for we soak in them in advance is prepared Petri dishes. 
Table 1. The list of chosen flowers for our experiment.

\begin{tabular}{|c|c|c|c|}
\hline № & Latin names of plants & English names of plants & Life form \\
\hline 1 & Antirrhinum L. & snapdragon & $\odot$ \\
\hline 2 & Aster L. & aster & ૫ \\
\hline 3 & Chrysanthemum L. & chrysanthemum & $\odot$ \\
\hline 4 & Dahlia Cav. & dahlia & ૫ \\
\hline 5 & Dianthus L. & carnation & ૫ \\
\hline 6 & Gerbera L. & gerbera & ૫ \\
\hline 7 & Gladiolus (Tourn) L. & gladiolus & ૫ \\
\hline 8 & Hyacinthus (Tourn) L. & hyacinth & ૫ \\
\hline 9 & Iris L. & iris & ૫ \\
\hline 10 & Lilium (Tourn) L. & lily & ૫ \\
\hline 11 & Narcissus L. & narcissus & ૫ \\
\hline 12 & Palonia L. & peony & ૫ \\
\hline 13 & Phlox L. & phlox & ૫ \\
\hline 14 & Rose L. & rose & ૫ \\
\hline 15 & Tulipa L. & tulip & ૫ \\
\hline
\end{tabular}

๑: one annual, ч: many annual plants.

Petri dishes are placed with filter paper, to the lower top wrapped in paper, sterilized to thermostats at the temperature of $120^{\circ} \mathrm{C}$. This Petri of dishes opened by flames of spirt, moisturize surfaced sterilization water.

After grinded plant of samples be held from the flames of spirt and be dialed on the dampened of filter paper. They will be again wrapped in paper, again to thermostat $\left(22^{\circ} \mathrm{C}-24^{\circ} \mathrm{C}\right)$. Later of $2-3$ days open the top cover of small plates and they will be assessed plant of slices.

After from the sprouting of fungi we planted by them to the lighters food environment items to the tubes. Good growing from the colonies preparation we discovered types of fungi.

Planned of research of experiments performance at the purpose detected types of fungi subsequently clean the save, for the full shootings of their signs of biological, ecological, morphological characters cultures we used adopted in the field of phytopathology and all scientists by has been used from the determinative [11]-[15].

\section{Results}

We determined systemic of types of fungi used from the Martin system given in Answer and Bisbi [16] (Table 2).

This is a Table 2 from the information as seen in, during the 3 years separated and have found disease 65 types, 9 and 1 variants in the form of fungi in flowers in Tashkent city and Tashkent region, grown in open fields and greenhouses. They are: 4 classes, 7 sections, 11 families and 30 categories.

Most species will be established types of fungi in Deuteromycotina class. They consist of 35 types and 5 form; after Basidiomycotina class 16 types; Ascomycotina 6-round, 4 form, 1 variants; Mactigomycotina consists of 5 types. The minimum micelle, sterility-group 3-round.

Than anyone has suffered types of fungi belonging Fusarium family includes tours-8 types and 6 form. Them provokes of diseases $F$. oxysporum f.sp. dianthi, F. oxysporum f.sp. chrysanthemi, $F$. oxysporum f.sp. glodioli, $F$. oxysporum f.sp. lilii, F. oxysporum f.sp. narcissi, F. oxysporum f.sp. tulipa and $F$. oxysporum are types of fusarium wilt, F. avenaceum, F. moniliforme, F. hetecosporium, F. solani, F. culmorum, F. gibbosum, F. redolens are types of fusarium rot.

After belonging to family of Botrytis 6 types-provokes are to delete the gray and spots. B. sinerea-Aster, Dahlia, Chrysanthemum, Carnation, Iris, Roses and plants; B. gladiolorum-Gladiolus; B. elliptica-Lily; B. narssicola-Narcissus; B. paeonia-Peony; B. tulipa-Tulip infection detected.

Fungi disease infects 13-round of flower plants: Puccinia antirrhini-Snapdragon; P. arenaria-Dahlia; P. chrysanthemiChrysanthemum; P. asters-Aster; P. gladioli-Gladiolus; P. iridis-Iris; P. schroeteri-Narcissus; Uromyces 
Table 2. Allocated from the flowers types of fungi and location of system.

\begin{tabular}{|c|c|c|c|c|}
\hline Class & Section & Family & Category & Types of fungi, their forms and variations \\
\hline \multirow{5}{*}{ Mastigomycotina } & \multirow{5}{*}{ Peronosporales } & \multirow{2}{*}{ Pythiaceae } & Pythium & P. debaryanum \\
\hline & & & Phytophthora & P. cryptogea \\
\hline & & \multirow{3}{*}{ Peronosporaceae } & Peronoplasmopara & P. sparsa \\
\hline & & & & P. antirrhini \\
\hline & & & Peronospord & P. lilii \\
\hline \multirow{11}{*}{ Ascomycotina } & \multirow{11}{*}{ Erysiphales } & \multirow{11}{*}{ Erysiphaceae } & & S. fuliginea f. dahlia \\
\hline & & & Sphaerotheca & S. macularis f.sp. rosae \\
\hline & & & & S. pannosa var. rosae \\
\hline & & & Frucinbe & E. cichoriacearum f. asteris \\
\hline & & & काутір & E. cichoriacearum f.phlogis \\
\hline & & & & S. bulborum \\
\hline & & & & S. gladioli \\
\hline & & & Solorotini, & S. paeoniae \\
\hline & & & scierotmid & S. sclerotiorum \\
\hline & & & & S. tuliporum \\
\hline & & & & Sclerotinia sp. \\
\hline \multirow{16}{*}{ Basidiomycotina } & \multirow{3}{*}{ Ustilaginales } & \multirow{3}{*}{ Ustilaginaceae } & Ustilago & U. violacea \\
\hline & & & Entyloma & E. dahlia \\
\hline & & & Urocystis & U. gladioli \\
\hline & \multirow{13}{*}{ Uredinales } & Melampsoraceae & Cronartium & C. flaccidum \\
\hline & & \multirow{12}{*}{ Pucciniaceae } & Dhmomidium & Ph. disciflorum \\
\hline & & & 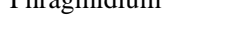 & Ph. tuberculatum \\
\hline & & & & U. caryophyllinus \\
\hline & & & Uromyces & U. lilii \\
\hline & & & & U. scillarum \\
\hline & & & & P. antirrhini \\
\hline & & & & P. arenaria \\
\hline & & & & P. asters \\
\hline & & & Puccinia & P. chrysanthemi \\
\hline & & & & P. gladioli \\
\hline & & & & $P$. iridis \\
\hline & & & & P. schroeteri \\
\hline \multirow{10}{*}{ Deuteromycotina } & \multirow{10}{*}{ Moniliales } & \multirow{10}{*}{ Moniliaceae } & Oidiopsis & O. phlogis \\
\hline & & & Oidium & O. chrysanthemi \\
\hline & & & 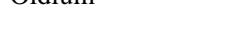 & O. erysiphoides \\
\hline & & & & P. corymbiferum \\
\hline & & & Penicillium & P. cyclopium \\
\hline & & & & P. gladioli \\
\hline & & & & B. cinerea \\
\hline & & & Petrotic & B. gladiolorum \\
\hline & & & Douytus & B. elliptica \\
\hline & & & & B. narcissicola \\
\hline
\end{tabular}




\section{Continued}

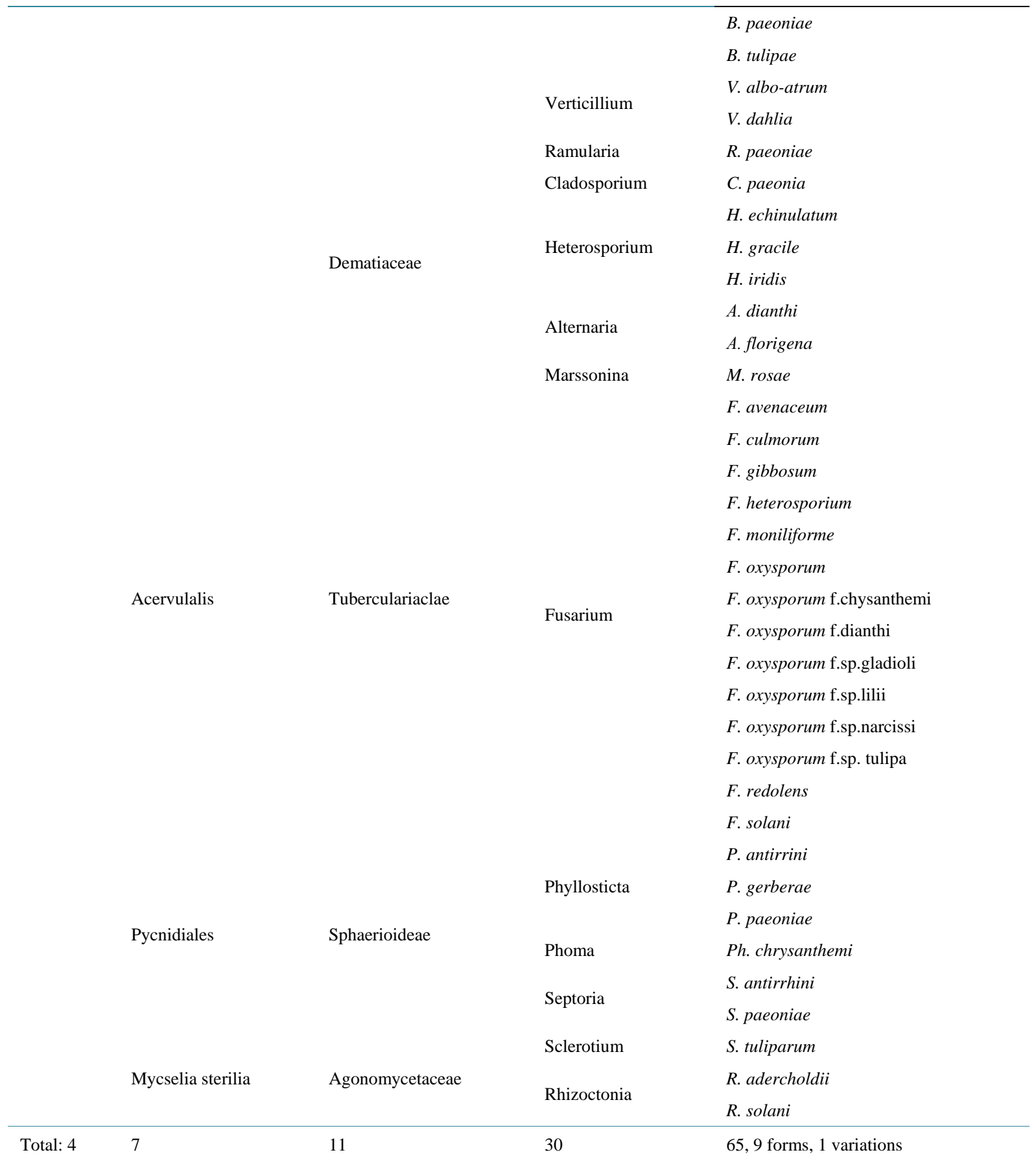

earyophyllinus—Carnation, U. lilie-Lily; U. scillarum—Hyacintha; Cronartium flaccidum—Peony, Phragmidium disciflorum, Phr. tuberculatum-Rose.

Powdery mildew are at 8 flower plants: Sphaerotheca fuliginca f.dahliae—Dahlia; Sph. macularis f.sp—Rose; Sph. pannosa. var.usae-Rose; Erysiph cichoracearum f. phlogis-Phlox; E. cichoracearum f. asteris-Aster; Oidium chrysanthemi-Chrysanthemum; O. erysiphoides_Gerbera; Oidiopsis-Phlox are diseasesed.

Sklerotinioz will attend the meeting 6 flower of plants of onions at the mildew.

In 10 pcs flower plants fixed of leaves and other members are Phyllosticta, Septoria, Alternaria, Heterosporium, Cladosporium, Ramularia marsonina, Penicillium belonging to families provokes of diseases a 16 pcs of 
types of fungi spots.

This of the spots of colors provokes of diseases fungi of types depends to are micelle, konidiya employment and konidiya. For example, will be like color of gray of spots at botrytis, color of brown-black or black at alternaria, color of green at penicillium and color of red at septoria.

This systematics provides an opportunity are determination of diseases and development them fighting measures.

\section{Conclusion}

During the conducting experiment we determined for the first time samples of 658 herbaria from 15 decorative flowers of plants in the field and greenhouses in Tashkent region. Of them pathogen disease separation determined 65 types of fungi to 9 form and 1 variants. 85 Disease determined at 15 types plants in conditions of Tashkent region. For the first time, we described their foreign symptoms, the morphological characteristics of fungal cultures in our republic, in Uzbekistan.

\section{References}

[1] Sobolev. L.E. (1987) Theoretical Aspects of Breeding Flower Cultures. Proceedings of the Nikitsky Botanical Garden, 101, 45-52.

[2] Naralieva, N.M. (2000) Tropical and Subtropical Plants in Room Conditions of Uzbekistan. Abstract of Dissertation for the Degree of Candidates of Biological Sciences, Tashkent, 2000.

[3] Parafiniuk, S. and Kopacki, M. (2012) Biological Efficacy of the Chemical Chrysanthemums Protection with the Use of Fine and Coarse Droplets. Journal of central European Agriculture, 13, 554-559.

[4] Richard, G.H. (2011) A Comparative Study of Phlox Paniculata Cultivars. Plant Evaluation Notes, 35, 1-10.

[5] Nagrale, D.T., Gaikwad, A.P. and Sharma, L. (2013) Morphological and Cultural Characterization of Alternaria alternata (Fr.) Keissler Blight of Gerbera (Gerbera Jamesonii H. Bolus ex J.D. Hook). Journal of Applied and Natural Science, 5, 171-178.

[6] El-Mougy, N.S. and Abdel-Kader, M.M. (2007) Antifungal Effect of Powdered Spices and Their Extracts on Growth and Activity of Some Fungi in Relation to Damping off Disease Control. Journal of Plant Protection Research, 47, 267-278.

[7] Golovin, P.N. (1960) Powdery Mildews Fungi Parasitizing on Cultivated Plants. M.-L. Science, Moscow.

[8] Ramazanov, S.S. (1975) Biology, Systematics of Fungi Rose Verticillium. Abstract of Dissertation for a Doctoral Degree in Biology, Tashkent, 1975.

[9] Hasanov, B.A., Achilov, R.O., Holmurodov, E.A. and Gulmurodov, R.A. (2010) Diseases of Fruit, Nuts, Citrus Fruit Trees, Berries, Vines and Fight with Them. OOO «Office Print», Tashkent.

[10] Mirpulatova, N.S and, Kireev, G.S. (1966) By the Method of Determining the Presence of the Fungus Verticillium dahliae in Soil. Proceedings of the Central Asian Institute of Plant Protection. Tashkent, 1990, 191-194.

[11] Khokhryakov, M.K. (1969) Methodical Instructions on the Experimental Study of Plant Pathogenic Fungi. Moscow-Leningrad Science, Moscow, 68.

[12] Naumov, N.A. (1937) Methods Mycological and Phytopathological Research. M.-L. Selkhozgiz, Moscow.

[13] Litvinov, M.A. (1967) The Determinant of Microscopic Soil Fungi. M.-L. Science, Moscow.

[14] Sinadsky, Y.V., Korneev, I.T. and Dobrochinskaya, I.B. (1982) Pests and Diseases of Decorative Flower Plants. M.-L. Science, Moscow, 592.

[15] Gorlenko, S.V. (1969) The Determinant of Illness Decorative Flower Plants. Harvest, Minsk.

[16] Ainsworth, G.C. and Bisby, G.R. (1971) Dictionary of the Fungi. Commonwealth Mycological Institute, 663 p. 